\title{
A visibilidade da heterodoxia científica
}

\author{
SEBASTIÃO J. FORMOSINHO*
}

\begin{abstract}
0 crescimento espectacular da Ciência deve muito à visão de Oldenburg ao associar as técnicas da imprensa às necessidades da comunicação científica quando organizou, em 1665, a primeira revista científica. É que as "cartas científicas" - hoje transformadas em artigos - pelo seu tamanho, esforço de preparação e rapidez de publicação, quando comparadas com o livro, constituem o meio adequado para a comunicação de uma ciência cumulativa e cooperativa. As revistas científicas constituem 0 arquivo público dos resultados e observaçōes experimentais, teorias, cálculos, algoritmos, etc. aos quais todos os cientistas do futuro podem recorrer para o estímulo de novas ideias ou aplicações, ou para exercer a crítica e a refutação, tendo em vista 0 progresso. A comunicação cientíica tornou-se assim inseparável do próprio método científico, não havendo ciência sem divulgação creditada.

Um artigo científico é uma oferta de um individuo ou grupo de indivíduos à comunidade científica. Porém, a aceitação de uma oferta requer o reconhecimento do estatuto de doador e este reconhecimento é realizado mediante uma "avaliação por pares". Outros cientistas, escolhidos pelo Editor da revista científi$\mathrm{ca}$, avaliam 0 interesse, validade e qualidade da informação contida no artigo submetido a apreciação. Estes avaliadores ou referees são elementos controversos no sistema de comunicação, uma vez que são também eles mesmos autores, 0 que origina alguns conflitos de interesse e resulta num delicado balanço no âmago da comunidade científica, sendo este 0 da avaliação daquilo que as próprias comunidades produzem. Mas é um sistema indispensável para creditar 0 material que entra no arquivo da ciência. É que os referees e os editores não se representam inteiramente a si mesmos, mas representam, por amostragem, 0 consenso científico que se estabeleceu no domínio e, por isso, têm o poder de conferir o imprimatur da autenticidade científica. A avaliação científica permite também uma separação dos artigos de boa e de má qualidade e uma hierarquização das revistas científicas [1, 2].
\end{abstract}

A história e a prática das ciências revelam a existência de um equilibrio delicado entre o valor consensual da informação científica e 0 direito da dissidência, potencial fonte de inovação. Pode mesmo parecer surpreendente que perante o dogmatismo de uma ciência construída à volta de paradigmas, hajam emergido heterodoxias inovadoras. Verifica-se empiricamente ao longo da história que a margem de segurança adoptada pelas comunidades não tem sufocado em absoluto o novo. Não que a história da ciência não registe profundas controvérsias, esquecimentos injustos e até procedimentos de censura. Mas exactamente por eles terem chegado ao nosso conhecimento, patenteiam alguma tolerância para com os dissidentes e alguma visibilidade da heterodoxia. Claro que estando 0 método científico disciplinado por ortodoxias que só permitem um certo grau de dissidência, os dissidentes científicos correm o risco de perder as suas credenciais como cientistas se divergem em demasia do consenso estabelecido [3]. Por estas e outras razões, as inevitáveis controvérsias científicas e a falta de um reconhecimento julgado adequado causaram problemas psicológicos de maior ou menor gravidade em cientistas empenhados como Boltzmann, Mayer, Cantor, Semmelweis, Torriceli, ou levaram ao simples abandono da ciência como com Waterston e Grassmann [4]. Mas julgo que a respeito de tais conflitos cognitivos pouco há a fazer, a não ser a prática de métodos científicos mais conducentes à flexibilidade mental [5], e alguma aprendizagem com as lições de história das ciências que os cientistas de cada geração teimam em ignorar na sua prática corrente [2].

0 que me suscita este artigo de opinião não são as dificuldades cognitivas que os cientistas revelam para assimilar conceitos novos. É a consciência de que recentemente vamos deparando com sintomas de alterações à margem de tolerância acima referida e cujas causas profundas podem matar a visibilidade das heterodoxias. Julgo mesmo que tais sistemas resultam de procedimentos correntes que não pretendem, de forma consciente, apagar os efeitos benéficos da dissidência no âmbito das ciências. Mas é preocupante que uma censura feroz suprima qualquer publicação de dissidência, porque sem um mínimo de visibilidade não há qualquer possibilidade de debate de ideias, controvérsias científicas ou mesmo reconhecimento tardio. Aquela ciência simplesmente não existiu. E não se diga que sempre que alguém falhou uma descoberta, outrém 0 fará inevitavelmente mais tarde, porque a evidência empírica não confere suporte a tais asserções [6].

Mas como se alterou o equilíbrio entre a ortodoxia e a dissidência? É que a aceitação do novo não está condicionada somente por factores cognitivos. Está-0 também por factores psicológicos, e pelo conjunto de interesses associados a um determinado campo científico e partilhados por uma dada comunidade. São interesses profissionais e de prestígio, de financiamento de investigação, intercâmbio científico, editoriais, económicos, de poder, etc. E tais interesses têm vindo a crescer perante a feroz competitividade entre cientistas, grupos de investigação, universidades e institutos de pesquisa, países, etc. Sintomas claros são o número crescente de fraudes científicas, particularmente nos domínios das Ciências da Vida e de que a revista Nature, entre outras tem feito eco de formas variadas [7]. 0 caso recente do medicamento AZT [8] para o combate à SIDA, que furando diversos dos protocolos científicos de validação, revelou-se por fim um "gigante de pés de barro". Houve mesmo um cientista, o Dr. Gordon Steward, professor jubilado da Universidade de Glasgow, que durante quatro anos viu recusado por diversas vezes a publicação de um artigo sobre a problemática colocada por este medicamento. 0 artigo só veio a ser publicado após ter rebentado 0 escândalo.

Mesmo na ausência de fraude, 0 conflito de interesses pode impedir muitos cientistas de acolherem heterodoxias que possam ameaçar o seu emprego, financiamento de investigação, estatuto 
profissional ou prestígio. Um relato profusamente documentado por argumentos de discordância oral e escrita com colegas, referees e editores é o do biologista celular $\mathrm{H}$. Hilmann [9]. Trata-se de um cientista britânico que travou uma dura batalha de 30 anos com editores $\mathrm{e}$ avaliadores para publicar as suas ideias em revistas cientificas, a maioria das vezes sem qualquer êxito e que, após a aposentação, publicou esta sua saga científica.

Muitos cientistas afirmarão, e correctamente, que mais de $90 \%$ da heterodoxia científica, é lixo e, como tal, não se perde nada, antes se ganha, em não o deixar vir a lume. Contudo, esta perspectiva tem de ser contrabalançada com a das lições da história das ciências, que vêm mostrando amplamente não ser o consenso científico um sinónimo de verdade. $E$ a ciência não se pode permitir o luxo de prescindir dos salutares efeitos do progresso daquela pequena percentagem que nalgum tempo foi heterodoxia e que, posteriormente, se veio a converter em consenso, paradigma e dogma. Mas a heterodoxia é também fonte de racionalidade ao acrescentar novas alternativas aos caminhos de ciência. Mesmo que seja um erro! Quantos erros científicos não contribuíram para a clarificação de ideias e 0 progresso da própria ciência. Ainda, e quiçá papel mais importante, a heterodoxia científica é um travão à estruturação de "ciência viciada".

A heterodoxia científica surge quando não há acordo entre os seus autores e a comunidade científica. Este desacordo tem de ser expresso através da rejeição de artigos contendo matéria heterodoxa e submetidos a publicação em revistas científicas com avaliação. Como critério operacional, só me parece legítimo considerar um tema científico como heterodoxo após 3 (mínimo 2) rejeições consecutivas em cerca de 3 (minimo 2) anos após a primeira submissão. Estes requisitos pretendem assegurar aos autores e à comunidade um tempo de reflexão e de reajuste de ideias antes de submeter todo o processo a uma instância de recurso. Atendendo a naturais reajustamentos do nível dos artigos à qualidade das revistas, parece-me mais adequado que as diferentes versões dos artigos tenham sido rejeitadas sucessivamente por revistas com factores de impacto cada vez menores (mas obviamente razoáveis).
Reconhecer a heterodoxia cientifica não é o bastante para a publicar. Carece ainda de ser avaliada, mas por critérios distintos do procedimento corrente. Criado um pequeno corpo de editores-juizes (aos quais estaria vedado este processo de recurso), os autores da heterodoxia submeter-Ihe-iam o processo de recurso com todas as versões dos artigos rejeitados e respectivos comentários dos editores e dos avaliadores. Para além deste material, apenas comprovativo do carácter heterodoxo da matéria em apreço, os autores apresentariam a nova versão do artigo que pretenderiam ver publicado, acompanhado de um resumo (não publicável), destinado a esclarecer, por forma adequada, os novos avaliadores-juízes no tocante aos quesitos da avaliaçãorecurso, adiante referidos. Um dos editores-juizes, actuando como presidente, enviaria a nova versão do artigo a 5 cientistas escolhidos pelo corpo de editores-juizes. Tais avaliadores-juizes devem ser cientistas com méritos já firmados e interesses diversificados, mas não devem ser especialistas na matéria em apreço, isto por dois tipos de razões. Primeiro, porque é entre os especialistas que 0 conflito de interesses poderá ser mais acentuado; segundo, porque os especialistas já foram consultados no processo normal de avaliação.

Cada avaliador-juiz deveria responder somente a três questões:

i) o tema do artigo é matéria científica?

ii) o trabalho contém erros de lógica? (em caso afirmativo indicar quais).

iii) se as afirmações do autor se viessem a revelar correctas, este facto revestir-se-ia de [grande, médio ou pouco] interesse cientifico?

A heterodoxia seria julgada em termos de uma minoria qualificada que se fixaria em 1/3. Assim o corpo de editores-juizes aceitaria 0 artigo para publicação quando em relação às duas primeiras questões houvesse pelo menos 2 respostas favoráveis, e em relação à terceira pelo menos 2 avaliadores - juízes indicassem um interesse médio.

No pressuposto de que um procedimento deste tipo recolhe 0 acordo das comunidades científicas, a publicação do artigo poderia fazer-se nalguma revista de uma sociedade científica ou em publicação criada para o efeito (por exemplo J. Heterodox Articles in Chemistry). 0 artigo deveria ser publicado com indicação de haver sido aprovado em instância do recurso, acompanhado ou não por algum comentário crítico de especialistas. Para efeitos de prioridade os autores poderiam reclamar 0 direito à indicação da data da primeira submissão.

Em suma, um artigo entendido como heterodoxo poderia demorar uns 5 anos a vir a lume. É um periodo longo, mas permissor de longa ponderação e atractivo só para cientistas muito empenhados e convictos da certeza das duas ideias. Contudo, este procedimento seria uma válvula de escape à situação vigente, respeitaria a independência intelectual dos autores, concedendoIhes crédito à sua capacidade científica normalmente patenteada em anteriores publicações, e poderia trazer, por um salutar efeito de retroacção, uma maior isenção e objectividade ao processo normal de avaliação.

\section{REFERÊNCIAS}

1. H.-D. Daniel, Angew. Chem. Int. Ed. Engl. 32 (1993) 234.

2. M.H. MacRoberts e B.R. MacRoberts, Spec. Sci. Techn. 3 (1980) 573.

3. M. Polanyi, Science 141 (1963) 1010.

4. H. Zuckerman e R.K. Merton, Phys. Today 25 (2) (1972) 9 .

\section{J.R. Platt, Science 146 (1964) 347.}

6. M. Ruderfer, Spec. Sci. Tech. 3 (1980) 533.

7. E. Racker, Nature (London) 339 (1989) 91; outros temas similares em ibid. 325 (1987) 181, 207, 215; 327 (1987) 550; Chem. Eng. News, (1989) Jan. 23, p. 5; July 3, p. 6; May 22, p. 27

8. H. Hillman, The Case for New Paradigms in Cell Biology, Edwin Millen Press, Lampeter 1991; recensão crítica em Chem. Britain, June 1992, p. 513.

*Universidade de Coimbra e Universidade Católica Portuguesa 
